\title{
UM CLÁSSICO POR AMADURECIMENTO: RAÍZES DO BRASIL*
}

\section{Luiz Feldman}

Em texto publicado em julho de 1950 no Diário Carioca, o então diretor do Museu Paulista e presidente da seção estadual da Associação Brasileira de Escritores, Sergio Buarque de Holanda, registrava o declínio do método interpretativo no estudo da História. A entronização do "fato puro" e a renúncia à imaginação poderiam representar, alertava, um retrocesso. $\mathrm{Na}$ verdade, além do empenho na coleta dos dados, era preciso que o historiador formulasse aos fatos "as perguntas realmente decisivas” (Holanda, 1996c, p. 234).

Não eram de outra ordem as indagações que, em Raizes do Brasil, Sergio Buarque havia dirigido

* Ao longo de sua preparação, este trabalho se beneficiou do estímulo e da crítica de Luiz Costa Lima, Maria Regina Soares de Lima, Silvana Seabra, Paulo Esteves, Robert Wegner, João Cezar de Castro Rocha e Leopoldo Waizbort, bem como de Emb. Everton Vargas e de dois pareceristas anônimos da RCBS. Erros e omissões são de exclusiva responsabilidade do autor.

Artigo recebido em 26/01/2011

Aprovado em 25/04/2013 ao processo de modernização do país. O livro fora publicado, em 1936, pela editora José Olympio, como número inaugural da Coleção Documentos Brasileiros, série que respondia, segundo o prefácio de Gilberto Freyre, à "ânsia de introspecção social que é um dos traços mais vivos da nova inteligência brasileira" (Freyre, 1936, p. v). Àquela altura, Sergio Buarque, bacharel em Direito, crítico literário e ex-correspondente na República de Weimar, ainda se iniciava na carreira de professor, como assistente das cátedras de História Econômica e Literatura Comparada da recém-criada Universidade do Distrito Federal. Raízes do Brasil só seria reeditado doze anos mais tarde, "consideravelmente modificado" ( $R B, 1948$, p. 11), de acordo com o autor. Dois decênios após sua vinda a lume, sairia em terceira edição, "com algumas alterações que não lhe afetam essencialmente o conteúdo" ( $R B, 1956$, p. 9), afiançava o escritor em novo prefácio. Após uma edição da Universidade de Brasília, em 1963, o tex- 
to definitivo foi publicado em $1969(R B, 2006)$ e, a partir daí, passou a ter sucessivas tiragens. ${ }^{1}$

Ao longo dessas edições, as mudanças feitas por Sergio Buarque afetaram não apenas as perguntas decisivas de 1936, mas também e sobretudo certas respostas cruciais oferecidas naquele momento, que foram objeto de significativas reorientaçôes. Por isso, delinear as preocupaçôes e as soluçôes apresentadas no livro é tarefa que requer abordagem diacrônica. O propósito deste artigo é cotejar as três primeiras ediçōes de Raizes do Brasile acompanhar a transformação do texto original em sua segunda e terceira versōes, porventura contribuindo, assim, para a releitura dessa obra clássica do pensamento social brasileiro por um ângulo que vem merecendo crescente atenção de seus comentadores, $o$ das "metamorfoses" sofridas pelo texto. ${ }^{2}$ Trata-se aqui, em outras palavras, tomadas a J. M. Coetzee (2002), de um exercício voltado a "interrogar o clássico", que se define como tal exatamente pela resistência que demonstra às interpelaçôes críticas que lhe dedicam diferentes geraçôes.

Em sua história já quase octogenária, Raizes do Brasil suscitou questionamentos desde os mais diferentes pontos de vista e a propósito de variados aspectos de sua composição. As interrogações a respeito da proposição e do enfrentamento dos dilemas ligados à passagem do tradicional ao moderno levaram a múltiplas avaliaçôes acerca da consistência, da pertinência e dos desígnios do livro. Assim, seriam encontradas, na armação enunciativa do ensaio, "contradiçāo lógica" (Leite, 1976), "ambiguidade profícua" (Piva, 2000), "universo tenso" (Monteiro, 2008), "metodologia dos contrários" (Candido, 2006a), "dialética negativa" (Wegner, 2000), "dialética contrapontística" (Vecchi, 2005) ou "síntese frágil" (Avelino Filho, 1987). As finalidades da obra incluiriam desde a defesa de um Estado forte como "resposta compatível com a situação brasileira" (Waizbort, 2011) até a proposta de uma "solução de cunho democrático-popular” (Candido, 1998).

Ao pôr em relevo importantes alteraçóes processadas em Raizes do Brasil entre 1936 e 1956, espera-se lançar luz sobre o fato evidente, mas ainda pouco explorado, de que a exatidão do que se afirma sobre esta obra de Sergio Buarque depende em importante medida da edição adotada como referência. Ao menos três ordens de mudanças empreendidas pelo autor explicam essa assertiva: $(i)$ a variação de sua postura axiológica acerca da tradição; (ii) a substituição do personalismo pela democracia como saída política para a nascente ordem urbana; e (iii) a reformulação do enunciado do desterro como condição característica do brasileiro.

Nas próximas três seçōes, o artigo examinará em detalhes cada um desses conjuntos de modificaçōes do ensaio, apontando os câmbios nas perguntas e nas respostas por ele formuladas e no método pelo qual as formula. Ao longo do texto, serão reunidos elementos que indicam que a própria narrativa do livro foi alterada. Sustenta-se que uma pragmática resignação com a cordialidade cedeu espaço a uma promessa de civilidade, tratada com ceticismo. Convém esclarecer que não se teve a pretensão de inventariar exaustivamente as alteraçōes no livro, e que a análise se limita às três primeiras edições, que concentram o esforço de reescrita do texto. Como conclusão, será possível dizer que, em um sentido que Antonio Candido (2006a) empresta à expressão, Raizes do Brasil não foi um "clássico de nascença”. Tornou-se clássico, na verdade, após mais de uma década de amadurecimento.

\section{Tradição}

O primeiro conjunto de alterações a assinalar-se diz respeito à temática da herança ibérica. $\mathrm{Na}$ edição princeps de Raizes do Brasil, há um questionamento básico sobre a resiliência da tradição diante do processo modernizador. Tratava-se de averiguar em que medida os ventos de mudança eram refreados pelo lastro do passado. Na segunda edição, o questionamento passa a referir-se às condiçōes para que o processo modernizador se efetivasse, ainda que em detrimento da tradição. Tratava-se agora de examinar as possibilidades de limitação do peso da história, de modo que se pudesse singrar com menos dificuldade rumo ao progresso.

Essas afirmações podem soar peremptórias quando se pensa que o ensaio de Sergio Buarque é caracterizado pela variação permanente do ângulo de análise (Wegner, 2006). É certo, contudo, que entre 1936 e 1948 ocorre um câmbio no juízo do autor acerca do valor da herança ibérica, com implicaçôes substantivas para a resposta que se encontra no livro à indagação sobre o papel da 
tradição. Isso sugere que o diagnóstico de que diferentes perspectivas estruturam o ensaio pode ser estendido e aplicado às várias ediçóes da obra, elas mesmas portadoras de diferentes perspectivas, que transitam da apreciação favorável do legado colonial à sua crítica e mesmo a seu repúdio. É o que se procurará verificar a seguir, sem desconhecer o papel aí desempenhado por outros fatores, como hesitações do autor e vestígios ou sobrevivências do texto de ediçôes anteriores. Tudo isso acentua o quadro de descontinuidades que caracteriza esse e, a acompanhar-se Adorno (2008), todo - ensaio.

É possível dizer que a narrativa concatenada pelo livro em 1936 assenta-se em uma avaliação de que o vigor da cultura do personalismo, da ética da aventura, do ruralismo e da cordialidade recomenda que se trate com reticência as perspectivas de modernização da sociedade brasileira. O tema está presente já na primeira página do ensaio, que anuncia o propósito de "averiguar até onde representamos nele [no ambiente brasileiro] as formas de vida, as instituições e a visão do mundo de que somos herdeiros e de que nos orgulhamos" ( $R B, 1936$, p. 3). Essa tomada de partido previne o leitor, de saída, contra uma interpretação simplista a respeito do papel da tradição, envolvendo-o em uma voz coletiva que se fortalece, ao cabo do primeiro capítulo, com uma alteridade bem delimitada: "a verdade, por menos sedutora que possa parecer [a] alguns dos nossos patriotas, é que ainda nos associa à Península Ibérica, e a Portugal especialmente, uma tradição longa e viva, bastante viva para nutrir até hoje uma alma comum" (idem, p. 15).

A herança ibérica estava, já se pode ver, bem representada nos usos e costumes nacionais. Mas, em uma apreciação inicial do valor do legado ultramarino para a formação independente do Brasil, feita no segundo capítulo, surge um juízo aparentemente desconcertante:

Assim, o peculiar da vida brasileira por essa época [a Colônia] parece ter sido uma acentuação singularmente enérgica do afetivo, do passional, do irracional, e uma estagnação, ou antes, um afrouxamento correspondente das qualidades ordenadoras, discriminadoras, racionalizadoras. Quer dizer, exatamente o contrário do que poderia convir a uma população em vias de se organizar politicamente, de acordo com os conceitos modernos (idem, pp. 32-33).

É significativa essa especificação do ângulo pelo qual o "afrouxamento das qualidades racionalizadoras" era inconveniente. A opção de considerar o personalismo (acentuação do afetivo) e a aventura (irracionalidade) impróprios é expressamente identificada ao ponto de vista dos "conceitos modernos", que se pode, ou não, adotar. Como se verá na próxima seção, para Sergio Buarque outro ângulo de visão era possível e mesmo necessário no tratamento da ordem política brasileira. Reveladoramente, na edição de 1948 o trecho é preservado ipsis litteris, exceto pela especificação ("de acordo com..."), que é suprimida (ver $R B, 1948$, p. 68). Isso torna o legado ibérico inconveniente de qualquer ângulo de análise - e justifica o desconcerto. Pode-se ver o Brasil começando a ser inscrito - por assim dizer - no "lado errado da história".

A leitura do terceiro e do quarto capítulos da edição de 1936, reunidos àquela altura sob o título comum "O passado agrário", não dá margem a essa virada crítica que se acaba de sinalizar no texto de 1948. Decerto, a narrativa da primeira edição pauta-se por uma "sintaxe da ausência", ${ }^{3}$ como ilustra o caso da moral religiosa (cf. Machado, 2008): "Mesmo à igreja católica [...] faleciam forças para organizar a sociedade anárquica da colônia” ( $R B, 1936, \mathrm{p}$. 82); e ainda: "Compreende-se que, em tais circunstâncias, não fossem esses padres uns modelos de virtude e ascetismo" (idem, p. 84). Mas as reiteradas indicações de que a formação brasileira não tivesse corrido de acordo com certo padrão internacional composto de democracia liberal, ética protestante e ética do trabalho (Wegner, 2000) - não servem de mote, na primeira edição, para a defesa de uma aproximação do Brasil às imagens refletidas nesse espelho de modernidade - ou, por outra, de civilidade. ${ }^{4} \mathrm{Na}$ verdade, essas indicações têm o efeito de um reconhecimento, por falta de alternativa, da força da realidade tal qual apresentada.

O episódio da "febre de progressos materiais" $(R B, 1936$, p. 46) que se seguiu ao fim do tráfico de escravos em 1850 é indicativo da atitude do autor. Embora estivesse em curso a passagem da "ditadura dos domínios rurais" à "urbanocracia” (idem, p. 50, 43), era preciso recordar que, com a urbanização, o 
“'espírito da casa-grande', estereotipado por centenas de anos de vida rural, [fora] transportado, bruscamente, de corpo e alma, para as cidades" (idem, pp. 46-47). Donde a transigência do autor na análise do ritmo vagaroso com que a modernização teria que ser processada: "Apenas não se pode dizer que o país estivesse amadurecido para grandes empreendimentos de ordem econômica que lhe alterassem profundamente a fisionomia. Eles não encontrariam facilmente, em nosso temperamento e em nossos costumes, um ambiente adequado, não obstante toda a boa vontade de certas elites" (idem, p. 46).

No plano político, não era outro o quadro. Centrada historicamente nos domínios rurais, a sociedade retirava deles seu princípio organizador, dado pelo tipo de família estruturado pelo direito romano canônico. "Resultava dessa circunstância", escrevia Sergio Buarque, um predomínio quase exclusivo, em todo o mecanismo social, dos sentimentos próprios à comunidade doméstica, naturalmente particularista e antipolítica, uma invasão do público pelo privado, do Estado pela Família. Explica-se largamente, com isso, a nossa adaptação difícil ao princípio do Estado democrático" (idem, p. 89).

Em suma, na economia, as mudanças "não encontrariam facilmente um ambiente adequado" e, na política, enfrentariam uma "adaptação difícil". Constatações como essas funcionam como uma espécie de reconhecimento do peso do status quo e não são seguidas por nenhum prognóstico de sua transformação. Indicavam, quando muito, a possibilidade da conciliação entre o tradicional e o moderno.

É interessante ler as mesmas passagens na segunda edição. O raciocínio sobre o "predomínio dos sentimentos próprios à comunidade doméstica" é mantido com mínimas reformulaçôes (ver $R B$, 1948 , p. 106), mas com a supressão decisiva da última frase ("Explica-se largamente..."). A correção evitava o entendimento de que a sociedade tivesse alguma inconciliabilidade de fundo com o regime democrático e ajudava a desimpedir o caminho para a "solução democrático-popular" que surgiria no sétimo capítulo da edição de 1948. Ao mesmo tempo que ajudava a abrir o plano político à possibilidade de transformação, deixava intacto o diagnóstico da “invasão do público pelo privado", óbice importante àquela transformação. Impasses como esse serão abordados, à frente, como expressóes de certo tipo de dialética que emerge no texto de 1948.

$\mathrm{Na}$ nova análise da "febre de progressos materiais", em 1948, o autor retoma a oposição entre afetividade e racionalidade sugerida no segundo capítulo. Se, na primeira edição, essa oposição admitia uma leitura que não descartava o valor do personalismo, agora, na segunda, sob o prisma exclusivo dos "conceitos modernos", a oposição proscrevia a ambiguidade e reservava ao personalismo e à aventura lugar de honra no polo negativo.

Eram dois mundos distintos que se hostilizavam com rancor crescente, duas mentalidades que se opunham como ao racional se opõe o tradicional, ao abstrato o corpóreo e o sensível, o citadino e o cosmopolita ao regional e o paroquial. A presença desses conflitos já parece denunciar a imaturidade do Brasil escravocrata para transformações que lhe alterassem profundamente a fisionomia [...] Como esperar mudanças profundas em país onde eram mantidos os fundamentos tradicionais da situação que se pretendia ultrapassar? [...] [A crise comercial de 1864] foi o desfecho normal de uma situação rigorosamente insustentável, nascida da ambição de vestir um país ainda preso à economia escravocrata com os trajes modernos de uma grande democracia burguesa. De certo modo, o malogro comercial de um Mauá também é indício eloquente da radical incompatibilidade entre as formas de vida copiadas de naçôes socialmente mais avançadas, de um lado, e o patriarcalismo e o personalismo fixados entre nós por uma tradição de origens seculares $(R B, 1948$, pp. 98-100).

Um primeiro fato a se notar no trecho é a aposição de "origens seculares" à tradição, qualidade nesse contexto antes depreciativa que solene, porque indicativa de uma renitência malsã. Em segundo lugar, atente-se para a intensificação da clivagem tradição-modernização, elevada a hostilidade rancorosa entre "dois mundos distintos", entre os quais há "radical incompatibilidade". Se na edição de 1936 já havia "metodologia dos contrários" - e não a havia em toda sua extensão, pois só na edição de 1948 aparece o ladrilhador como contraparte do semeador (ver 
$R B, 1936$, cap. 4) -, só agora se pode dizer que o par racional-tradicional tivesse sido ativado em uma oposição que expressasse, no texto, um conflito fundamental. Em 1936, o "racional" simplesmente não era um fator dinâmico que antagonizasse a tradição. Em terceiro lugar, deve-se sublinhar que a expectativa de "mudanças profundas" não se encontrava no texto original, mas é agora confessada ostensivamente pelo autor, infundindo à narrativa certa premência modernizadora que antes não se percebia. $\mathrm{O}$ reconhecimento do peso da história passa a conviver com a expectativa de que incida sobre a realidade nacional um movimento de profunda transformação. A "sintaxe da ausência" é complementada, na segunda edição, por uma "semântica da presença", relacionada, de modo amplo, ao "racional", ao "abstrato", ao "citadino" e ao "cosmopolita”. Como se verá adiante, essa semântica inscreve no horizonte do possível uma promessa da civilidade, sem chegar a concretizá-la.

$\mathrm{O}$ autor expande as considerações sobre o tema com outros acréscimos que faz aos capítulos três e quatro de Raizes... na edição de 1948 . O conflito de mentalidades é ilustrado pela referência - antes inexistente no terceiro capítulo - à concepção da ciência econômica como busca de redução do volume de trabalhos manuais, proposta pelo visconde de Cairu. Tratava-se, aduz Sergio Buarque, de princípio oposto "ao sentido de todo o pensamento econômico oriundo da Revolução Industrial”, a qual se pautava pelo "ideal da completa despersonalização do trabalhador" (idem, p. 110). Em uma nota incluída ao fim do quarto capítulo, o autor propõe que a mentalidade capitalista requeira atributos morais que "São virtudes antes de tudo lucrativas, que [...] procuram sobrepor [...] aos vínculos pessoais e diretos a crescente racionalização da vida" (idem, p. 193n). O acréscimo desses trechos é digno de registro, não só porque conferem à narrativa da despersonalização e da racionalização um matiz favorável que dificilmente se encontra na edição de 1936, mas porque contrastam vivamente com a desaprovação do utilitarismo e com a defesa da índole nacional por Sergio Buarque em mais de um texto de juventude (Holanda, 1996a, 1996b, 2011b). A revisão de pressupostos na década de 1940 impõe, assim, interrupções à "linha de continuidade" que já se traçou entre as primícias do jornalista e crítico dos anos de 1920 e o livro de estreia do historiador que se anunciava na década de 1930 (Avelino Filho, 1987). Em 1948, a obra torna-se menos reconhecível do que em 1936 à vista dos textos de Sergio Buarque na década de 1920.

Tal como reconstruída até aqui, a disjunção entre a argumentação das edições de 1936 e de 1948 envolve, naquela, a reticência frente às perspectivas de implante da modernização (para a qual seria necessária, no mínimo, uma composição com as estruturas existentes) e, nesta, a necessidade de algum tipo de ruptura com o tradicional para a implantação do moderno. As modificações no capítulo "O homem cordial", o quinto do livro, dinamizam a busca de soluções a esses impasses no trânsito do passado ao futuro.

O conceito de cordialidade foi proposto por Sergio Buarque a partir dos contornos delineados em 1931 por Rui Ribeiro Couto (2006). O poeta e diplomata adiantara a ideia de uma "atitude de disponibilidade sentimental”, associada à hospitalidade e à credulidade, atributos que singularizariam o homem cordial frente ao "resto da humanidade" (Couto, 2006, p. 397). Tratava-se, para ele, de "Atitude oposta [à] do europeu: a suspicácia e o egoísmo do lar fechado a quem passa” (idem). Cinco anos mais tarde, Sergio Buarque adotaria de bom grado a expressão do amigo: "O escritor Ribeiro Couto teve uma expressão feliz, quando disse que a contribuição brasileira para a civilização será de cordialidade - daremos ao mundo o homem cordial” (RB, 1936, p. 101).

O primeiro traço a assinalar-se na cordialidade associada a "um fundo emocional extremamente rico e transbordante" ( $R B, 1936$, p. 101) - é a força inercial que empresta à tradição: "A lhaneza no trato, a hospitalidade, a generosidade, virtudes tão gabadas pelos estrangeiros que nos visitam, formam um aspecto bem definido do caráter nacional" (idem). Além disso, e por via de consequência, a cordialidade era pragmaticamente apontada (no sexto capítulo) como vetor capaz de transformação da realidade: a riqueza emocional era "a única força criadora que ainda nos restava" (idem, p. 126). Ou seja, ainda que um caminho de civilidade se tornasse possível (alternativa depois examinada no livro), a cordialidade seria incontornável: "até para que essa civilidade conseguisse impor-se de forma mais ajustada, mais articulada 
entre nós, com um custo político menor, ela deveria levar em conta esse 'miolo', esse centro cordial" (Araújo, 2000, p. 42). Por fim, dentro do programa modernista de "aprofundamento do local como contribuição ao universal” (Avelino Filho, 1987, p. 34; ver Monteiro, 2012a, p. 317), cumpre notar que a ideia de um aporte brasileiro ao mundo condiz com outro propósito anunciado na página inicial do livro, o de "investigar até que ponto poderemos alimentar no nosso ambiente um tipo próprio de cultura" $(R B, 1936$, p. 3).As modificações na edição de 1948 e também na de 1956 alteram sensivelmente essa perspectiva. Desde logo, em uma das correções mais prenhes de consequências para a releitura do livro, Sergio Buarque recua da aproximação entre cordialidade e caráter nacional - ou se precavê contra o risco de que seu texto fosse lido nessa direção:

A lhaneza no trato, a hospitalidade, a generosidade, virtudes tão gabadas por estrangeiros que nos visitam, representam, com efeito, um traço definido do caráter brasileiro, na medida, ao menos, em que permanece ativa e fecunda a influência ancestral dos padrôes de convívio humano, informados no meio rural e patriarcal (RB, 1948, pp. 213-214).

Anexa-se um cuidadoso condicionamento espacial e temporal ao fenômeno. $\mathrm{O}$ procedimento seria reforçado na terceira edição, com a inclusão, em Apêndice, da carta do autor a Cassiano Ricardo (RB, 1956, pp. 311-314; ver Ricardo, 1959, cap. 1). Sergio Buarque atentava para a aceleração do processo de ruptura daqueles padrões de convívio típicos da cordialidade:

Associo-a [a cordialidade] antes a condições particulares de nossa vida rural e colonial, que vamos rapidamente superando. Com a progressiva urbanização [...] o homem cordial se acha fadado provavelmente a desaparecer, onde ainda não desapareceu de todo. E às vezes receio sinceramente que já se tenha gasto muita cera com esse pobre defunto" ( $R B, 1956$, pp. 313-314).

Embora o tema caiba à próxima seção, pode-se constatar brevemente o espaço que se abre, com essas alterações, para o processo de implantação da civilidade. Se na edição de 1936 a civilidade estava em larga medida ausente, devido à notável força de permanência da cordialidade, a partir de 1948 torna-se plausível buscar uma "semântica da presença" referida às imagens modernas e modelares da democracia liberal, da ética do trabalho e até mesmo da ética protestante. A antítese cordialidade-civilidade é intensificada e poderá estabelecer, nos capítulos finais de Raízes do Brasil, uma dialética sem síntese.

Outra frente de modificação aberta em 1948 e aprofundada em 1956 diz respeito à reversão de mal-entendidos gerados pelas imprecisões no conceito de cordialidade (Rocha, 2004), ao menos daqueles para os quais o próprio autor contribuiu. $\mathrm{O}$ fenômeno refere-se à confusão ou equiparação da cordialidade com a ideia de bondade. A certa altura do texto da edição de 1936, lê-se: "Com a cordialidade, a bondade, não se criam os bons princípios" ( $R B, 1936$, p. 156). O uso da vírgula entre os dois períodos cria uma "relação propriamente sinonímica" que "estreita o vínculo semântico entre cordialidade e bondade" (Rocha, 2012, p. 18). Na edição de 1948, o autor resolve a questão riscando o período intermediário: "Com a simples cordialidade não se criam os bons princípios" ( $R B, 1948$, p. 279). Quando se recorda o otimismo irradiado por Ribeiro Couto em 1931, não se afigura de todo implausível supor que também Sergio Buarque concebesse, em 1936, uma dimensão positiva da cordialidade, ligada à bondade. Essa valoração estaria referida ao programa modernista de "exaltação de nossa peculiaridade", sobre o qual Sergio Buarque falaria com distanciamento crítico em 1951 (Holanda, 1996d, p. 341), mas com o qual já se viu ter tido contato seu pensamento da década de 1920 e também a edição de 1936 do livro, que cogitava da formação de um "tipo próprio de cultura".

Em nota de rodapé ao capítulo cinco, publicada na edição de 1948, o autor esclarece - ou melhor, retifica - a questão e afirma que a cordialidade "não abrange [...], apenas e obrigatoriamente, sentimentos positivos e de concórdia. A inimizade bem pode ser tão cordial como a amizade, nisto que uma e outra nascem do coração, procedem, assim, da esfera do íntimo, do familiar, do privado" ( $R B$, 1948 , p. 214 n, grifos do autor). Esse acréscimo foi, 
em suas palavras, uma "ampliação" da explicação $(R B, 1956$, p. 313). Mas a definição da cordialidade também como inimizade torna frágeis, no mínimo, a celebração e a singularização do brasileiro ou dos latino-americanos, na versão de Ribeiro Couto - por contraste à "suspicácia" e ao "egoísmo" típico dos europeus. Desaparece do texto o sentido benigno e mesmo edificante da assertiva de que "daremos ao mundo o homem cordial". Na verdade, em 1948 e especialmente em 1956, todo este trecho é esvaziado de qualquer dimensão substantiva. "Também não creio muito", lê-se na carta anexa à terceira edição, "na tal bondade fundamental dos brasileiros. Não pretendo que sejamos melhores, ou piores, do que outros povos" ( $R B, 1956$, p. 313, grifo do autor). Nem a escolha da expressão "cordial", antes elogiada, resiste à ampla neutralização e inversão do valor da tradição no argumento do livro: "Se dela me apropriei foi na falta de melhor" (idem, p. 311). É natural, ao fim e ao cabo, que tenha sido excluído do texto de 1948 o entendimento da cordialidade como "força criadora" (ver $R B, 1948$, p. 243).

É possível concluir esta seção, dedicada aos capítulos de Raizes do Brasil que tratam do passado brasileiro, com o registro de uma nítida variação de perspectiva entre a primeira e a segunda e a terceira edições no que se refere à temática da tradição. De obstáculo firme à modernização, que impunha a necessidade de uma composição, quando não uma resistência obstinada do quadro tradicional, a herança ibérica é reconfigurada na segunda e na terceira edições por uma desagregação cada vez mais veloz. A busca da limitação do peso da história concretiza-se nas modificações operadas no conceito de cordialidade, as quais têm o condão de dinamizar o processo modernizador. A modernização aponta para a consolidação do espaço público, a despersonalização e a racionalização - diferentes dimensões da civilidade, que, entretanto, não chegam a projetar, em sua antítese aos elementos constitutivos da cordialidade, alguma forma de síntese. Nenhuma dessas dimensões parece mais conduzir à formação de um "tipo próprio de cultura" no Brasil. Pelo contrário: indicariam a inserção do país em uma ordem mais afim à do Ocidente - de certo Ocidente. O tema será retomado na terceira seção do artigo. Verificou-se, pela abordagem diacrônica das três primeiras edições do livro, a pertinência da descrição da cordialidade como "um dos termos mais instáveis do pensamento social brasileiro" (Melo, 2011, p. 93). A transmutação do "homem cordial" em "pobre defunto" tem tanto maior relevo quanto se compreende a cordialidade como "conceito-síntese" do tradicionalismo brasileiro discutido no livro (Avelino Filho, 1990).

\section{Revolução}

O segundo conjunto de alterações a destacar-se em Raízes do Brasil diz respeito à temática do progresso político. A ampla reconfiguração da sociedade brasileira a partir do século XIX, condensada pela urbanização, implicava a procura de um ordenamento político condizente com as novas realidades. A indagação que orienta Sergio Buarque nos capítulos seis e sete da edição princeps é sobre a possibilidade de que a democracia se firmasse como solução a esse desafio. Buscando o moderno, encontra o tradicional: avalia que as tentativas de organização da política nacional pela doutrina democrática são infrutíferas, porque se desviam do único solo onde poderia vicejar a estabilidade, o personalismo. A segunda edição não é orientada por questionamento substancialmente diverso do proposto em 1936, mas lhe fornece solução diametralmente oposta. Na análise amplamente revisa$\mathrm{da}$, o personalismo obstrui a democracia e deve ser erradicado para que esta possa ser implantada em profundidade. Mantida a interrogação, chega-se a uma resposta - e resposta verdadeiramente crucial completamente diferente. A "Nossa revolução" (título do sétimo capítulo) será reinvestida de sentido, um sentido disjuntivo em relação ao que tivera anteriormente. Essa mudança reitera e adensa o já aludido câmbio de perspectivas entre edições.

A divergência entre as versões de 1936 e 1948 manifesta-se inicialmente, no sexto capítulo, em torno da célebre afirmação de que a democracia é um mal-entendido no país. Lia-se na primeira edição:

Trouxemos de terras estranhas um sistema completo e acabado de preceitos, sem saber até que ponto se ajustam à vida brasileira [...] A democracia no Brasil foi sempre um lamentável mal-entendido. Uma aristocracia rural e semifeudal 
importou-a e tratou de acomodar-se como lhe fosse possível às suas leis, que tinham sido justamente a bandeira de combate da burguesia europeia contra os aristocratas $(R B, 1936$, p. 156).

Na segunda edição, o texto diz:

Trouxemos de terras estranhas um sistema complexo e acabado de preceitos, sem saber até que ponto se ajustam às condições da vida brasileira e sem cogitar das mudanças que tais condiçóes lhe imporiam [...] A democracia no Brasil foi sempre um lamentável mal-entendido. Uma aristocracia rural e semifeudal importou-a e tratou de acomodá-la, onde fosse possível, aos seus direitos ou privilégios, os mesmos privilégios que tinham sido, no Velho Mundo, o alvo da luta da burguesia contra os aristocratas $(R B, 1948$, p. 238).

Observe-se, primeiramente, a mudança nos termos da crítica à importação da democracia. Em 1936, o desajuste entre o "sistema completo e acabado" e a "vida brasileira" soa irremediável. Em 1948, o "sistema complexo" admite, embora também seja "acabado", algum ajuste em face das condições locais. A questão é a inexistência de uma atitude crítica capaz de realizá-lo, obsedadas como estavam as inteligências bacharelescas pelo "poder milagroso das ideias" (idem, p. 236). Importa reter, contudo, a ideia de que o sistema de governo importado era passível de adequação, isto é, mais uma vez em 1948 Sergio Buarque desobstruía o caminho rumo a uma solução democrática. Observe-se, em seguida, a forma pela qual a importação se deu. No texto de 1936, a aristocracia "tratou de acomodar-se" aos princípios democráticos. No de 1948, a elite "tratou de acomodá-la”, a democracia, aos privilégios aristocráticos. Sobressai, no texto da segunda edição, a crítica à classe dominante e ao esvaziamento do programa democrático pelo tradicionalismo, ausentes na versão original. É sintomático o acréscimo, páginas além, da apreciação de que os bacharéis - "nossa intelectualidade" - revelariam uma "missão nitidamente conservadora e aristocrática” (idem, p. 246).

O problema para a edição de 1936 era bem outro. Em um pequeno artigo sobre o pensamento de Carl Schmitt publicado um ano antes na Folha $d a$
Manhã, Sergio Buarque constatava que, havia até pouco tempo, as ideias do liberalismo "pareciam ter alcançado para a generalidade dos homens essa 'posição irrefutável' a que aspiram, por definição, todos os programas políticos. À luz de qualquer raciocínio sólido só elas podiam fazer jus a um posto de honra em nosso planeta" (Holanda, 1988, p. 298). No livro, o autor reparava na adoção acrítica dessa doutrina por uma elite desorientada pela drástica mudança em suas condições de vida, com a passagem do mundo rural para o urbano. Acreditando-se liberais - "se veem diversos do que são" $(R B, 1936$, p. 161) -, os bacharéis dominantes desdenhavam da herança ibérica e, com ela, de "nossa própria riqueza emocional, a única força criadora que ainda nos restava" (idem, p. 126). "Tudo assim se engenhava na fabricação de uma realidade artificiosa e livres$\mathrm{ca}$, onde nossa vida verdadeira morria de asfixia" (idem). A República fora especialmente suscetível a esse "bovarismo", centrado na "ideia de que o país não pode crescer pelas suas próprias forças naturais: deve formar-se de fora para dentro, deve merecer a aprovação dos outros" (idem, p. 131, grifo do autor). "Não quer dizer", afirmava Sergio Buarque no ensaio "Corpo e alma do Brasil", prelúdio de Raizes publicado em 1935, "que o Império representasse em todos os sentidos uma forma definitiva, ou sequer o gérmen de um sistema orgânico com o substratum da nacionalidade. É indiscutível, porém, que estava menos longe disso que a República" (Holanda, 2011a, p. 78). É este o sentido em que se poderá ler a afirmação de que o Estado, e especialmente a República, no Brasil, "se empenha em desarmar todas as expressões genuínas e menos harmônicas de nossa sociedade, em negar toda a espontaneidade nacional" $(R B, 1936$, p. 144). O trecho é imediatamente seguido por uma citação de Alberto Torres, para quem a política era, "de alto a baixo, um mecanismo alheio à sociedade, perturbador de sua ordem, contrário a seu progresso" (Torres apud idem).

A negação de vetores "genuínos", tais como o personalismo, capazes de estruturar o campo político nacional, se fazia em proveito da adesão acrítica a um formalismo jurídico vazio de substância e contraproducente do ponto de vista do progresso. Este, na lógica da primeira edição, o mal-entendido da democracia. Como fica evidente, o autor não 
adotava, aqui, o ângulo de visão sugerido pelos "conceitos modernos", contumazes na censura à "acentuação singularmente enérgica do afetivo, do passional, do irracional". Eram estes, justamente, os elementos adequados a uma população que buscava sua organização política em meio às circunstâncias sociológicas dadas pela formação brasileira. Esse reconhecimento da indisponibilidade de outras "forças criadoras" empresta cariz pragmático à resignação diante da cordialidade, ressaltado na discussão sobre o personalismo, à frente.

O autor refere-se com ironia aos "nossos teóricos e sábios" que pretendiam, "ainda hoje”, deter as fórmulas definitivas para a modernização do Brasil, guiados pelo "prestígio moderno e provavelmente efêmero das superstiçóes liberais e protestantes" (RB, 1936, p. 128). Assevera então: "os pensamentos e conselhos que eles nos servem visariam criar, ao termo de nosso [sic] evolução, um quadro social milagrosamente destacado de nossas tradições portuguesas e mestiças" (idem). Esta passagem (inclusive a má aposta na fugacidade do prestígio daquelas "superstiçôes") desaparecerá, por inteiro, na edição de 1948. Duas páginas à frente, ao comentar a "miragem da alfabetização", oferece apreciação similar: "Assim, vão os nossos homens apegando-se a ficções e a vaticínios enganosos, que servem para disfarçar um invencível desencanto de nossa realidade e de nossa tradição" (idem, p. 130). Na segunda edição, a passagem restringir-se-á a mencionar "um invencível desencanto em face das nossas condiçōes reais" ( $R B, 1948$, p. 249).

O sentido desse par de retificações na edição de 1948 é inequívoco. De um lado, desaparece a reticência com roteiros de modernização que desconsiderassem as balizas "portuguesas e mestiças", bem expressa em 1936 na alusão cortante ao caráter "milagroso" de soluções que não contemplassem algum tipo de composição entre tradicional e moderno. De outro, exclui-se precisamente a crítica àqueles que se revelavam desencantados com "nossa tradição". Em outras palavras, anulava-se o "orgulho" que a tradição inspirava, mencionado no começo do primeiro capítulo da edição de 1936 ( $R B, 1936$, p. 3$)$, curiosamente mantido em $1948(R B, 1948$, p. 16) e afinal suprimido em 1956 $(R B, 1956$, p. 15$)$.
As significativas exclusões no texto do capítulo seis suscitam uma justificada dúvida sobre qual o sentido "remanescente" da argumentação. O cotejo das duas edições mostra que a discussão sobre o "desencanto com a realidade", que antes tivera um papel limitado no capítulo, ganha protagonismo. Esclareça-se: a preocupação central da primeira edição recaía sobre o "desencanto com a tradição", a qual era apenas parte, conquanto importante, da realidade. O novo encadeamento argumentativo do sexto capítulo parte, como se viu, da discussão sobre o esvaziamento do programa democrático pelo personalismo. ${ }^{5}$ A crítica que dirige em 1948 à elite é diferente daquela feita em 1936: antes, a desorientação com circunstâncias da vida urbana levava ao descrédito da tradição e à improfícua adesão às doutrinas liberais; agora, uma estratégia conservadora de preservação do tradicional status aristocrático ditava a sistemática "indiferença [...] ao conjunto social” ( $R B, 1948$, p. 243).

Nessa nova leitura, é possível compreender que o "secreto horror à nossa realidade" (idem, p. 236) não deixava de ter efeitos perversos, como na sugestão de luminares positivistas do tempo da fundação da República de que o Brasil fosse subdividido em duas esferas de cidadania: a dos habitantes que descendiam da fusão das três raças e a das "hordas fetichistas esparsas pelo território" (Lemos e Mendes apud idem, p. 235). O autor retorna ao assunto quando, no sétimo capítulo, menciona o silêncio destinado ao tema da escravidão ao longo do século XIX: "os políticos mais prudentes preferiram não mencionar o ponto vulnerável de uma organização que aspiravam perfeita e coerente consigo mesma [...] Criaram asas para não ver o espetáculo detestável que o país lhes oferecia” (idem, p. 280). Embora essas passagens já constassem do livro em 1936, pode-se dizer que, realçadas pela supressão da temática do desencanto com a tradição e pela inclusão de assertivas críticas ao conservadorismo da elite, ganharam na edição de 1948 maior importância. O problema da exclusão social repontava em Raizes do Brasil, e se poderia ler, nesses trechos, uma indagação sobre como se conceber uma sociedade com tais fraturas a partir das ideias de nação e de comunidade (cf. Arantes, 2006).

Nesse ponto pode-se volver a atenção ao derradeiro capítulo do livro, "Nossa revolução". A pri- 
meira diferença entre o texto das edições de 1936 e 1948 está na passagem de Nietzsche citada na epígrafe da primeira versão e excluída na segunda: "Um povo perece quando confunde seu dever com o conceito geral de dever" (Nietzsche, 2011, p. 21, grifo do autor). $\mathrm{Na}$ leitura que propõe da primeira edição de Raizes do Brasil, Leopoldo Waizbort (2011) observa que esta epígrafe funciona como uma coerente transição entre a conclusão do capítulo seis - com sua crítica à ideia de que o país "deve formar-se de fora para dentro" - e a proposta do capítulo sete - o personalismo como ponto de fuga do quadro político nacional. "O conceito de dever é aquele valor alienígena", anota, "estranho ao povo - no caso em pauta, a democracia. $\mathrm{O}$ verdadeiro triunfo de um povo está no reconhecimento e na assunção de seus instintos e sentimentos os mais vivos; o povo triunfa quando segue sua própria natureza, no caso o personalismo" (Waizbort, 2011, p. 43). É interessante perceber que, com a invocação de Nietzsche, o campo semântico da civilidade, já precário na edição de 1936, contaminava-se, adicionalmente, com a imagem do perecimento: "O que não é uma condição vital é nocivo à vida [...] A 'virtude', o 'dever', o 'bem em si', o 'bem' como o caráter da impessoalidade e da validade universal são quimeras em que se expressa a decadência, a debilitação final da vida" (Nietzsche, 2011, p. 21, grifos do autor).

Essas observações encontram amparo no raciocínio que se surpreende, na sequência do capítulo sete, sobre a importação de ideais europeus pelos países latino-americanos à época de suas independências.

E dessa forma os povos de nossa América Latina foram levados a enaltecer um sistema de ideias que contrastava em absoluto com o que há de mais positivo em seu temperamento e que, bem compreendido, levaria à total despersonalização. [...] Uma superação da doutrina democrática só será possível, efetivamente, quando tenha sido vencido $[s i c]$ a antítese impersonalismo-caudilhismo. Seja como for, o fato é que o espírito legístico não conseguiu, até hoje, modificar profundamente a atitude natural dos povos latino-americanos que pretende orientar [...] Entre nós, já o dissemos, o personalismo é uma noção positiva - talvez a única verdadei- ramente positiva que conhecemos. Ao seu lado todos os lemas da democracia liberal são conceitos puramente decorativos, sem raízes fundas na realidade. Isso explica bem como nos países latino-americanos, onde o personalismo - ou mesmo a oligarquia, que é o prolongamento do personalismo no espaço e no tempo - conseguiu abolir as resistências da demagogia liberal, acordando os instintos e os sentimentos mais vivos do povo, tenha assegurado, com isso, uma estabilidade política que de outro modo não teria sido possível. A formação de elites governantes em torno de personalidades prestigiosas tem sido, ao menos por enquanto, o princípio político mais fecundo em nossa América $(R B$, 1936, pp. 149-152).

O trecho é notável a mais de um título. Em primeiro lugar, pela conclusão a que leva a discussão, iniciada no capítulo anterior, sobre a "demagogia liberal”. Reitera-se no sétimo capítulo, inclusive, a afirmação da democracia como mal-entendido (ver idem, p. 153). A prospecção malsucedida de pontos de contato profundos entre cordialidade e democracia (idem, pp. 153-157) reforça a avaliação de que, na edição de 1936, não chega a haver uma dialética entre cordialidade e civilidade, e sim predomínio daquela sobre esta. Ao sublinhar a falta de organicidade do liberalismo no terreno sociopolítico nacional, o livro remete à sua metáfora organizadora: a busca das "raízes fundas na realidade". Estas ainda são, expressamente, as ibéricas, e suas fortes ramificaçōes populares dão razão à ausculta de ressonâncias nietzscheanas no argumento do capítulo. Ademais, à diferença do que vai de nostálgico em um Casa-grande \& senzala, a resignação com a tradição tem no Raízes do Brasil de 1936 fundamento pragmático, não apenas pela já assinalada inexistência de alternativas, mas também porque o personalismo é garantia de uma estabilidade política que só pode ser alcançada por seu intermédio. ${ }^{6} \mathrm{Em}$ segundo lugar, a longa citação notabiliza-se pela clareza com que avança a visão política de "superação da doutrina democrática" por meio de um arranjo estruturado pelo personalismo, "princípio político mais fecundo" na região. Parece prematura a identificação, na lógica da primeira edição (mas não na da segunda, já se verá), de uma 
perspectiva radical de "profundas transformações nos quadros sociais" (Monteiro, 1999a, p. 269). Havia no texto uma defesa inequívoca da oligarquia (extensão espaciotemporal do personalismo), entendida como "uma espécie de decantação da alma popular, que saberia expressar" (Waizbort, 2011, p. 42).

Essa leitura é radicalmente alterada pela substituição do personalismo pela democracia como saída política na edição publicada três anos após o fim do Estado Novo e do término do conflito mundial. Observe-se, preliminarmente, que a supressão de alguns trechos e a manutenção de outros retira da narrativa do capítulo sete o encadeamento fluido que se apresentava em 1936. Para citar apenas um exemplo, a referência capital à "superação da doutrina democrática” ( $R B, 1948$, p. 269) é preservada, mas intriga o leitor, pois este se depara, logo a seguir, com o seguinte acréscimo: "Essa vitória [da antítese liberalismo-caudilhismo] nunca se consumará enquanto não se liquidem, por sua vez, os fundamentos personalistas [...] onde ainda assenta nossa vida social" (idem, pp. 269-270). A superação da doutrina democrática, que antes era motivada pelo retorno às raízes ibéricas, depende agora de que essas mesmas raízes sejam aniquiladas. Páginas adiante, descobre-se que, segundo o novo raciocínio, "onde quer que o personalismo - ou a oligarquia [...] - conseguiu abolir as resistências liberais, assegurou-se, por essa forma, uma estabilidade política aparente, mas que de outro modo não seria possível” (idem, p. 276). O principal dado positivo do personalismo, sua capacidade de estabilizar o conjunto social, torna-se mera impressão. Inutilizados os arranjos oligárquicos como princípios capazes de vertebrar a vida política nacional, atinge-se o cerne da questão.

Sergio Buarque altera por completo o rumo de seu argumento, apresentando o inédito juízo de que,

Se o processo revolucionário a que vamos assistindo, e cujas etapas mais importantes foram indicadas nestas páginas, têm um significado claro, será a dissolução lenta, posto que irrevogável, das sobrevivências arcaicas, que o nosso estatuto de país independente até hoje não conseguiu extirpar [...]É possível que algumas das suas fases culminantes [dessa revolução] já tenham sido ultrapassadas, sem que possamos avaliar desde já sua importância transcendente. Estaríamos vivendo assim, para recorrer às expressôes de Mathew [sic] Arnold, entre dois mundos: um definitivamente morto e outro que luta por vir à luz. Escrevendo há sessenta anos, com intuição verdadeiramente divinatória, um naturalista norte-americano pôde anunciar, em forma de aspiração, o que não está longe, talvez, de constituir realidade [...] "De uma revolução", dizia [Herbert Smith], "é talvez o que precisa a América do Sul. Não de uma revolução horizontal, simples remoinho de contendas políticas, que servem para atropelar algumas centenas ou milhares de pessoas menos afortunadas. $\mathrm{O}$ mundo está farto de tais movimentos. O ideal seria uma boa e honesta revolução, uma revolução vertical e que trouxesse à tona elementos mais vigorosos, destruindo para sempre os velhos e incapazes". De que maneira se efetuaria essa revolução? "Espero", responde Smith, "que quando vier, venha placidamente e tenha como remate a amalgamação, não o expurgo, das camadas superiores; camadas que, com todas as suas faltas e os seus defeitos, ainda contam com homens de bem. Lembrai-vos de que os brasileiros estão hoje expiando os erros dos seus pais, tanto quanto os próprios erros. A sociedade foi mal formada nesta terra, desde as suas raízes. Não ouso afirmar que, como classe, os operários e tendeiros sejam superiores aos cavaleiros e aos grandes negociantes. A verdade é que são ignorantes, sujos e grosseiros [...] Mas o trabalho dá-lhes boa têmpera, e a pobreza defende-os, de algum modo, contra os maus costumes" (idem, pp. 270-272).

Deslindava-se, para o leitor de 1948, o sentido definitivo - e aclamado - da "Nossa revolução". Contrariamente ao que fora dito havia doze anos, a revolução caminhava para eliminar, e não para fortificar ou remodelar, as "sobrevivências arcaicas". A cordialidade, outrora "única força criadora", transmutava-se em elemento "velho e incapaz". O progresso, e com ele a própria ideia de independência, passava a depender da superação do passado e da implantação do moderno.

O par elite-massa deixa de ser respectivamente equiparado (ainda que com ironia) "[ao] nosso 
Ethos e [ao] nosso Eros" (RB, 1936, p. 124, grifos do autor). O povo, abordado em sua concretude histórica, torna-se depositário do "papel de substituir as lideranças da sociedade" (Candido, 2004, p. 249). Essa expectativa dá novo sentido à afirmação de que "as instituiçôes republicanas deviam representar a forma exterior complementar" do fenômeno da "urbanização contínua, progressiva, avassaladora" ( $R B, 1948$, p. 262). O problema da exclusão social, acentuado na narrativa do sexto capítulo de 1948, começa a receber algum encaminhamento político. Cumpre recordar a formulação, naquele mesmo capítulo, do juízo de que, embora importada, a democracia era passível de ajuste ao quadro local. A menção específica de Alberto Torres à política como perturbação da ordem (tradicional) da sociedade é suprimida, permanecendo, porém, o trecho de seu $O$ problema nacional brasileiro em que aludia à perspectiva de um "surto social robusto e progressivo" (Torres apud idem). Bem entendida, a noção de progresso passava a referir-se - na lógica de Raizes do Brasil - aos benefícios advindos do fechamento do hiato entre Estado e sociedade, também lembrado por Torres.

A manter-se o critério de um sistema político "orgânico com o substratum da nacionalidade", para voltar às palavras do autor em 1935, enfrentava-se agora o desafio da sincronização democrática entre o Estado (e a civilidade) e um substratum em franca transformação (cf. Bosi, 2003, p. 261). Para dar coerência à nova narrativa, o autor retira o adjetivo "genuínas" que qualificava as "expressōes menos harmônicas de nossa sociedade" ( $R B, 1948$, p. 265). Se o Estado seguia a desarmá-las, era antes por um déficit democrático do que por renegar as forças tonificantes - em que pese malquistas pela elite bacharelesca - da tradição. Liberta dos comportamentos instintivos ("genuínos") que lhe ensinou a formação ibérica, a "espontaneidade nacional" podia enriquecer-se do aporte multitudinário e multifário dos elementos que fermentavam as mudanças, como os imigrantes, a cidade e a indústria (Candido, 1998). A propósito não seria exagerado ajuntar que a "boa têmpera" conferida aos operários pelo trabalho, se ainda distava consideravelmente de ensejar uma ética própria, sinalizava sem dúvida um mundo de práticas ou experiências desligado da valorização aristocrática da "digna ociosidade" $(R B$, 1936, p. 47; cf. Holanda, 1996e, pp. 317-318), projetando o trabalho em uma fase pós-ibérica.

Um das principais alteraçoes diz respeito à referência ao naturalista norte-americano Herbert Smith, cuja crítica ao sistema político personalista do país em Do Rio de Janeiro a Cuiabá (Smith, 1922) merecera da edição de 1936 uma censura pela "incompreensão intolerante que é forçoso existir entre dois estilos de vida radicalmente diversos" ( $R B, 1936, \mathrm{p}$. 151). Agora, em 1948, o autor é louvado pela "intuição verdadeiramente divinatória" do vaticínio sobre a "revolução vertical", retirado de seu Brazil: the Amazons and the coast (Smith, 1879). De singular importância é o reposicionamento semântico da metáfora organizadora das "raízes", que reconfigura integralmente a dinâmica entre tradição e modernização. Quem deve lançar "raízes fundas na realidade" é, a partir da segunda edição, essa "revolução vertical", substantivamente mais próxima da civilidade do que da cordialidade. A virada do jogo enunciativo do livro é arrematada com esta afirmação verdadeiramente emblemática da nova narrativa de Raizes do Brasil: "A sociedade foi mal formada nesta terra, desde as suas raízes". A importância desta frase, "núcleo temático fundamental" da obra (Vecchi, 2005), aumenta ao se verificar o cuidado que teve Sergio Buarque na escolha das palavras para a tradução do original de Herbert Smith, onde se lia: "Society here was wrongly constituted in the outset" (Smith, 1879, p. 476). Salta à vista o investimento metafórico das opçōes: here por nesta terra; wrongly constituted por mal formada; in the outset pelo simbólico desde as suas raizes.

$\mathrm{O}$ processo que se anuncia nada tem de simples. Em vez do retorno decidido à tradição, proposto na primeira edição, ou de um salto pujante para o futuro, vivia-se "entre dois mundos". Um definitivamente morto - mais enfático do que o dead do poema de Matthew Arnold (1994) -, o outro que luta por vir à luz - sensivelmente menos pessimista do que o powerless to be born da redação original. ${ }^{7}$ Emergia, com clareza, uma "temporalidade residuária do presente",

[...] intuição profunda, histórica, da vida nacional, onde um tempo regressivo e um outro progressivo forjam a contemporaneidade, con- 
trastando precocemente os dualismos e as fáceis dialéticas do contexto periférico. Nele, o que emerge com força é um tempo opaco onde os conflitos ficam em aberto, sem uma conciliação viável, tempo trágico por excelência (Vecchi, 2005, pp. 167-168, grifo suprimido).

Vêm à mente a "inquietação social de nossos dias" ( $R B, 1948$, p. 204), e mesmo a "instabilidade constante de nossa vida social” (idem, p. 31), devida à caducidade do personalismo como princípio estabilizador. Essa decadência já era registrada no primeiro capítulo da primeira edição, mas convivia com a defesa do personalismo no longo trecho do sétimo capítulo há pouco citado. Com a avaliação, na segunda edição, de que a estabilidade política gerada pelo personalismo era "aparente", os capítulos de abertura e encerramento da obra ganhavam coerência.

No tempo trágico que marca o limiar "entre dois mundos", o ponto de equilíbrio entre a cordialidade remanescente e a civilidade emergente é elusivo, como indica o parágrafo final da obra:

Poderemos ensaiar a organização de nossa desordem segundo esquemas sábios e de virtude provada, mas há de restar um mundo de essências mais íntimas que, esse, permanecerá sempre intacto, irredutível e desdenhoso das invenções humanas [...] Já temos visto que o Estado, criatura espiritual, opõe-se à ordem natural e a transcende. Mas também é verdade que essa oposição deve resolver-se em um contraponto para que o quadro social seja coerente consigo. Há uma única economia possível e superior aos nossos cálculos para compor um todo perfeito de partes tão antagônicas (idem, p. 284).

Passagens como essa, com seu jogo cerrado de proposiçôes e contramodulaçôes sobre a dinâmica entre geral e particular - as invençôes e as essências, o espírito e a natureza, o todo e as partes - revelam como o conflito entre as ordens familiar e urbana verte da realidade brasileira e espraia-se na própria lógica do texto (Monteiro, 2008, p. 352). O estilo da escrita revela como a enunciação se torna, ela mesma, parte integrante do esforço de reconstrução dos nexos de uma complexa realidade histórica
(Monteiro, 1999b, p. 156). Nesse sentido, um trecho cujo alcance era tolhido pela solução personalista esposada pela primeira edição pode, na segunda, ser lido em seu pleno tensionamento, que fecunda dialeticamente o texto: "Não existe, entre o círculo familiar e o Estado, uma gradação, mas antes uma descontinuidade e até uma oposição [...] Só pela superação da ordem doméstica e familiar é que nasce o Estado [...] Há nesse fato um triunfo nítido do geral sobre o particular" (RB, 1948, p. 203).

Desse complexo campo enunciativo não é lícito retirar conclusões categóricas. $\mathrm{O}$ próprio autor não se arrisca além de soluções precárias, como indica a noção de "contraponto" entre civilidade e cordialidade. Pode-se, todavia, registrar o fortalecimento da antítese cordialidade-civilidade na segunda edição de Raizes do Brasil. No texto original, embora já remetesse à abstração e à polidez (RB, 1936, pp. 101-103), a civilidade quase não se associava à despersonalização e à racionalização. E, conforme se viu, tornava-se ambígua pela proximidade à imagem do perecimento. Na segunda edição, é possível dizer que a narrativa polariza-se com clareza entre cordialidade e civilidade. Com isso, a civilidade assume uma presença - ou, mais exatamente, uma promessa - mais ponderável na história brasileira: o efetivo "triunfo do geral sobre o particular". O contraponto entre cordialidade e civilidade já foi descrito por Robert Wegner como uma "dialética sem síntese", na qual "o polo da cordialidade desaparece e reaparece sem se encontrar com sua antítese” (Wegner, 2000 , p. 223). Seriam esses os termos da nova resposta oferecida por Sergio Buarque, em 1948, à pergunta sobre o enraizamento da democracia.

\section{Desterro}

O terceiro conjunto de alteraçôes a registrar-se em Raizes do Brasil diz respeito à temática do desterro como condição característica do brasileiro. $\mathrm{Na}$ edição princeps, a situação de desterro é definida pelo descompasso entre o transplante bem-sucedido da cultura ibérica para a sociedade brasileira e a equívoca pretensão da elite local de fundar uma ordem política assentada em inorgânico modelo político-jurídico. O desterro era, àquela altura, outra forma de nomear o mal-entendido da democracia. 
$\mathrm{Na}$ segunda edição, todo o primeiro parágrafo da obra, que contém a passagem relativa ao desterro, reproduz o texto da versão de 1936 . Contudo, as amplas modificações na narrativa do livro impedem que se repita a leitura anterior. Termos importantes do parágrafo em questão ganham mais de um sentido ou perdem-nos por completo, e o enunciado do desterro assume grande complexidade. Na terceira edição, o autor faz modificaçôes importantes na redação dos parágrafos de abertura, tornando suas perguntas e respostas consistentes com a argumentação que já era apresentada desde 1948. O desterro passa a referir-se a um estado de suspensão temporal, ou irresolução, entre cordialidade e civilidade. Nessa nova enunciação, o mal-entendido da democracia - já destituído da componente de desencanto com a tradição portuguesa - torna-se apenas uma das partes do problema.

Uma providência básica para a compreensão do enunciado sobre o desterro na edição de 1936 é a leitura detida do primeiro parágrafo do ensaio, a começar por suas duas frases iniciais:

Todo estudo compreensivo da sociedade brasileira há de destacar o fato verdadeiramente fundamental de constituirmos o único esforço bem-sucedido, e em larga escala, de transplantação da cultura europeia para uma zona de clima tropical e subtropical. Sobre território que, povoado com a mesma densidade da Bélgica, chegaria a comportar um número de habitantes igual ao da população atual do globo, vivemos uma experiência sem símile $(R B, 1936$, p. 3$)$.

Observe-se, em primeiro lugar, o significado da expressão "cultura europeia". A sequência do primeiro capítulo do livro, intitulado "Fronteiras da Europa”, cuidará de destacar o fato de que a formação cultural do continente não podia ser compreendida unitariamente. Portugal e Espanha, de par com a Rússia, os países balcânicos e até a Inglaterra, são definidos como "territórios-ponte, pelos quais a Europa se comunica com os outros mundos. Assim, eles constituem uma zona fronteiriça, de transição, menos carregada, por isso mesmo, desse europeísmo que, não obstante, mantém como um patrimônio" (idem, p. 4). Em face dessa clivagem entre alta e baixa intensidade de "europeísmo", a referência de Sergio Buarque a um transplante bem-sucedido para o Brasil dirige-se claramente à parcela da "cultura europeia" proveniente da península Ibérica, região "indecisa entre a Europa e a África" (idem). As abundantes referências do livro ao profundo arraigamento do iberismo no Brasil a partir da Colônia o confirmam.

Observe-se, em segundo lugar, a menção a uma "experiência sem símile", intimamente relacionada à proposta de investigação sobre "até que ponto poderemos alimentar no nosso ambiente um tipo próprio de cultura”. O sucesso do transplante da cultura ibérica não impedia que, em sua evolução, a sociedade local adquirisse feições próprias. A cordialidade, que Sergio Buarque distingue da experiência tipicamente portuguesa (ver $R B$, 1936, p. 103), é dita "contribuição brasileira para a civilização". Recuperando, como já se observou (Rocha, 2004), um raciocínio desenvolvido pelo conde Affonso Celso em Porque me ufano do meu pais, o autor indica que o território nacional poderia vir a comportar "número de habitantes igual ao da população atual do globo". Por essa razão, a cultura que nele se desenvolvia poderia ter impacto significativo sobre expressiva parcela da população mundial. A cordialidade franquearia, em larga escala, uma "alternativa em relação ao processo clássico da racionalização/impessoalização sofrido pelas culturas europeias" (Avelino Filho, 1990, p. 8). (Cabe esclarecer que essas "culturas europeias" seriam, no caso, aquelas que Sergio Buarque diria de "europeísmo carregado".) O Brasil tornava-se terra com nada menos que um notável potencial renovador para os destinos da humanidade. Com pouco exagero, poder-se-ia dizer que a narrativa que conjugava a apreciação favorável da tradição ibérica à visão política da oligarquia como fonte de estabilidade culminava com o elogio da cordialidade como alternativa aos rigores da modernidade ocidental. A "experiência sem símile" poderia elevar-se a uma contribuição civilizacional. Nesse ponto, a resignação pragmática daria lugar ao entusiasmo. Esse "desfecho" da obra tinha na increpação de Ribeiro Couto (2006) contra a suspicácia e o egoísmo predominantes na Europa um antecedente intertextual imediato. Relacionava-se, igualmente, à crítica de 
Oswald de Andrade (2001) à "dessolidarização" causadora do egoísmo contemporâneo. E, de modo mais amplo, à tendência modernista, simbolizada por Oswald, que vislumbrava uma subversão do modelo civilizacional europeu pela composição entre moderno e tradicional (Wegner, 2009, p. 215).

Atendo-se a análise ao texto de 1936, é preciso dizer que a resposta de Sergio Buarque à indagação sobre a formação de um "tipo próprio de cultura" não é mais que exploratória. Ele não chega a delineá-la para além da menção à cordialidade, e uma das poucas indicações de seu desenvolvimento é a afirmação, na última frase do parágrafo inicial do livro, de que "todo o fruto de nosso trabalho ou de nossa preguiça participa fatalmente de um estilo e de um sistema de evoluçóes naturais a outro clima e a outra paisagem" $(R B, 1936$, p. 3$)$. Esse "sistema" não chegaria a ser exclusivamente brasileiro, pois a cordialidade e o personalismo definiriam "o que há de mais positivo" no "temperamento" dos povos de toda a América Latina. A inserção do Brasil no mundo como território marcado por traços hispânicos e sem europeísmo carregado, em geral associada ao projeto intelectual de Gilberto Freyre (Vargas, 2007), também podia ser identificada, na primeira edição de Raízes do Brasil, em Sergio Buarque. Para Pedro Meira Monteiro, a indagação sobre o "tipo próprio de cultura" era bem própria ao momento em que o livro veio a lume. A denúncia do liberalismo podia encontrar-se, "antes do Estado Novo e da Segunda Guerra, [...] com a tese de que, afinal, a experiência ibérica na América constituíra um outro conceito do político, que o relativo sucesso ulterior do mundo liberal sepultaria por muito tempo" (Monteiro, 2010, p. 188; ver Monteiro, 2012b, p. xiii). Essa apreciação reforça o entendimento de que a diferença de perspectiva entre as edições do livro torna as afirmações que sobre ele se façam dependentes, em importante grau, da versão do texto que se tenha em consideração.

Precisado o sentido das duas frases iniciais da edição de 1936, pode-se reler o parágrafo de abertura, agora com o acréscimo de sua terceira (e penúltima) sentença:

Todo estudo compreensivo da sociedade brasileira há de destacar o fato verdadeiramente fundamental de constituirmos o único esforço bem-sucedido, e em larga escala, de transplantação da cultura europeia para uma zona de clima tropical e subtropical. Sobre território que, povoado com a mesma densidade da Bélgica, chegaria a comportar um número de habitantes igual ao da população atual do globo, vivemos uma experiência sem símile. Trazendo de países distantes as nossas formas de vida, nossas instituições e nossa visão do mundo e timbrando em manter tudo isso em um ambiente muitas vezes desfavorável e hostil, somos ainda uns desterrados em nossa terra $(R B, 1936$, p. 3$)$.

Uma leitura possível desse trecho iria na direção de que a afirmação sobre o desterro (terceira frase) contradiz frontalmente a afirmação sobre o transplante bem-sucedido (primeira frase). Estaria dado o paradoxo, sem dúvida instigante, de um país a um tempo enraizado e desenraizado (Rocha, 2004, p. 114). No entanto, do ponto de vista deste artigo, a passagem pode ser interpretada com base na leitura do conjunto da narrativa da primeira ediçāo, ${ }^{8}$ logrando-se desarmar o mencionado paradoxo.

A chave de compreensão está no tema do "mal-entendido da democracia". Como se viu, este se explica pela adoção acrítica de um modelo jurídico-político de organização do Estado que prejudica o país ao impermeabilizar-se à "espontaneidade nacional" e ao desprezar as expressóes autênticas e tonificantes da nacionalidade de raiz ibérica. É esse o problema central dos capítulos de Raizes do Brasil voltados à problemática política contemporânea, $\mathrm{e}$ é nesse âmbito que Sergio Buarque critica as "superstiçōes liberais" sem "raízes fundas na realidade" e advoga o retorno ao solo histórico fértil para o progresso, o personalismo. Nessa interpretação, o desterro remete aos esforços malogrados e deletérios de cultivo de uma forma política incompatível com o meio latino-americano. Assim, é possível compreender como a frase sobre o desterro contrasta a vicissitude presente (desenraizamento) com o êxito passado (enraizamento), e anuncia ao leitor o dilema de uma prática política bacharelesca descompassada da cultura ibérica. A "transplantação" bem-sucedida da cultura ibérica é complementar, e não contraditória, à condição de desterro. $\mathrm{O}$ sucesso do transplan- 
te ibérico é justamente a razão pela qual são "ainda uns desterrados em nossa terra" os brasileiros que buscam nutrir, em solo brasileiro, um implante natimorto. O desenraizamento deriva do desencanto bovarista com a tradição. Será recordado que mesmo o americanismo, alternativa ao iberismo, não passaria àquela altura de uma "sorte de exacerbamento de manifestações estranhas, de decisões impostas de fora, exteriores à terra" $(R B, 1936, \mathrm{p} .137)$.

A interpretação aqui proposta reforça-se com uma leitura cerrada da terceira frase do parágrafo inicial. A famosa afirmação sobre o desterro é precedida por duas oraçôes. A primeira diz respeito ao fato de que "nossas formas de vida", "nossas instituiçôes" e "nossa visão do mundo" sejam trazidas de "países distantes". A segunda diz respeito ao fato de que essas formas, instituições e visão sejam mantidas em "ambiente muitas vezes desfavorável e hostil". Lidas como uma decorrência das frases anteriores ("Todo estudo compreensivo..."; e "Sobre território que..."), essas orações conduziriam logicamente a um dilema. Se a cultura ibérica fora enraizada com sucesso incomparável, como seria possível que o mesmo ambiente que a recebera engendrasse, concomitantemente, seu desenraizamento? E como explicar que uma região com a qual o Brasil mantinha uma "alma comum" fosse reduzida a "países distantes"?

Lendo-se as orações em análise como enunciados independentes daqueles das frases anteriores, que os modulam em lugar de os prolongar, chega-se a outro resultado, consistente com a interpretação que se vem propondo. Em vez de se referirem à cultura transportada com sucesso à época da colonização, as formas de vida, instituições e visão do mundo podem ser associadas à importação malograda e acrítica, a partir do século XIX, das "superstiçõos liberais e protestantes", que nada tinham de orgânicas com o solo histórico brasileiro. Exatamente porque timbrava para manter-se em solo ibérico, essa importação enfrentava um "ambiente muitas vezes desfavorável e hostil". Nessa leitura, soa natural a menção a "países distantes", pois o intervalo cultural entre os dois lados dos Pirineus excedia em muito o espaço geográfico que separava o Brasil da península Ibérica.

O primeiro parágrafo da edição de 1936 constituiria, em resumo, uma espécie de síntese do dilema político enfrentado pelo livro: a herança ibérica havia aberto um lugar especial (ou ao menos viável) para o Brasil no concerto das nações, mas o país vinha negando seu potencial ao pretender-se diverso do que podia ser.

$\mathrm{Na}$ edição de 1948, o texto dos parágrafos de abertura é idêntico, descontados mínimos ajustes de estilo (ver $R B, 1948$, pp. 15-16). O autor continua declarando o Brasil "experiência sem símile" de "transplantação" da "cultura europeia" e propondo-se a examinar até que ponto o país representava as formas de vida, instituições e visão de mundo "de que somos herdeiros e de que nos orgulhamos" (idem, p. 16). No entanto, não será preciso repisar as inúmeras modificaçōes na segunda edição que negam valor ao legado colonial e enaltecem a civilidade para que se compreenda o valor puramente nominal dessa semelhança. O "orgulho" e a busca do "tipo próprio de cultura" perdem sentido e se tornam um resquício do texto anterior. A “cultura europeia” em transposição já não pode ser limitada à de aquém-Pirineus, ibérica, mas engloba a de além-Pirineus, que (com alguma latitude) se diria ocidental. Ao passo que na primeira edição o transporte cultural restringia-se - na frase inicial ao conteúdo ibérico fixado no Brasil, na segunda edição ele engloba o novo processo histórico de transferência dos conteúdos ocidentais para o país em urbanização. Com esse duplo emprego, o autor conferiu sentidos disjuntivos ao termo "cultura europeia”: a referência pode ser tanto à cordialidade, cuja atual decadência não é escondida pelo sucesso de seu antigo transplante, quanto à civilidade, cuja promessa ainda não é realizada devido à incipiência de seu implante. É certo que essa ambivalência não contribui para a clareza da exposição do livro. Mas a instabilidade do termo "cultura europeia" é fecunda, uma vez que aproxima o significado do desterro à condição aporética (ou de impasses) própria ao "viver entre dois mundos". Daí não se poder dispensar o primeiro parágrafo da versão de 1948 como uma mera sobrevivência equívoca.

Tal perspectiva será confirmada e aprofundada na edição de 1956, que erige o desterro em um dos principais enunciados de Raízes do Brasil. Veja-se o texto afinal revisado da página de abertura:

A tentativa de implantação da cultura europeia em extenso território, dotado de condições na- 
turais, se não adversas, largamente estranhas à sua tradição milenar, é, nas origens da sociedade brasileira, o fato dominante e mais rico em consequências. Trazendo de países distantes nossas formas de convívio, nossas instituições, nossas ideias, e timbrando em manter tudo isso em ambiente muitas vezes desfavorável e hostil, somos ainda hoje uns desterrados em nossa terra $(R B, 1956$, p. 15$)$.

$\mathrm{Na}$ aparência, o trecho não se afigura radicalmente diverso. A primeira frase, embora reescrita, segue referindo-se à temática do transporte cultural, e a segunda é mantida com alterações pontuais. Entretanto, os enunciados em jogo são consideravelmente modificados. Tome-se, inicialmente, o câmbio na redação da frase inicial. $\mathrm{O}$ vocábulo "implantação" remete à presença de um corpo estranho, diferentemente de uma "transplantação", que sugeria uma inserção orgânica. Trata-se, ademais, de uma "tentativa", gradação amplamente inferior ao "esforço bem-sucedido" de 1936. Por isso, é pouco plausível relacionar a "tentativa de implantação" à cultura ibérica, pois o "lento cataclismo" desta (idem, p. 251) ocorreria depois de mais de três séculos de pleno e bem-sucedido arraigamento, reconhecido como tal pelo autor. A "implantação" refere-se, com mais razão, à reduplicação da ordem ocidental no Brasil (ver Santiago, 2006), calcada na democracia liberal e na ética do trabalho, afora a ética protestante. A segunda frase do parágrafo mantém evidente complementaridade com a primeira: o desterro decorre da situação incerta que vem de ser descrita. Observe-se, na frase sobre o desterro, a substituição das expressões "formas de vida" e "visão de mundo" por "formas de convivência" e "ideias", câmbio que remonta ao afastamento do autor em relação ao arcabouço analítico germânico recorrente na edição dos anos de 1930 (Rocha, 2012; Waizbort, 2011). É importante assinalar, finalmente, o acréscimo de um advérbio de tempo na última oração da segunda frase: "somos ainda hoje uns desterrados em nossa terra". O vocábulo "hoje" aproxima toda essa frase, e mesmo a anterior (dado que o que se traz dos "países distantes" é precisamente o que se tenta implantar no "extenso território"), aos problemas do presente e aos obstáculos à civilidade.
Antes de prosseguir, importa fazer um breve esclarecimento. Sergio Buarque afirma, sobre a "tentativa de implantação", que ela constitui "fato dominante" "nas origens da sociedade brasileira". Esse marco temporal pode ser plausivelmente referido aos momentos de gênese do Brasil independente (ou urbano), e não aos do Brasil Colônia. Como se sabe, é a partir do século XIX que - segundo a narrativa de Raizes do Brasil - a civilidade passa a ser objeto de uma tentativa de implantação. No texto da primeira e da segunda ediçôes, diferentemente, a "origem" em questão remetia com clareza à etapa colonial da sociedade brasileira: "único esforço bem-sucedido, e em larga escala, de transplantação da cultura europeia para uma zona de clima tropical e subtropical”.

Resta avaliar o sentido da reconfigurada condição de desterro no texto de 1956. A nova redação do parágrafo inicial ressalta a problemática da inorganicidade cultural ("implantação") e dos obstáculos políticos à modernização ("tentativa”). O processo a que se liga o desterro não é mais o bovarismo (embora o envolva), e sim a "Nossa revolução", que aprofunda o quadro instaurado com a Abolição: "1888 representa o marco divisório entre duas épocas" ( $R B, 1948$, p. 89). O desterro passa a relacionar-se àquela contemporaneidade forjada entre um tempo regressivo e outro progressivo, no qual os conflitos não têm conciliação viável, e a dialética não dispõe de síntese. A armação enunciativa do livro fica "suspensa num entre que é conexão - mas também hiato" (Vecchi, 2005, p. 170, grifo do autor). $\mathrm{O}$ tom celebratório da experiência sem símile passa a dar lugar à "suspensão temporal interminável" (Finazzi-Agrò, 2005, p. 148) do desterro, agregando uma perspectiva cética ao processo de democratização - vale dizer, à "Nossa revolução". Coloca-se em questão a própria configuração da identidade nacional, ou mais exatamente a ausência desta, pois o desterro se tornaria "via para o descentramento, para a desprovincianização" (Rouanet, 2006, p. D2), e talvez mesmo "metáfora da condição existencial do brasileiro" (Rocha, 2005, p. 13). O alinhamento entre "tentativa de implantação" e "desterro" é decisivo para o jogo enunciativo. Agora há desterro justamente porque o implante da civilidade é, por enquanto - a duração é indeterminável -, uma tentativa. A ausência de paradoxos na formulação do parágrafo inicial não diminui 
o interesse do livro, como talvez se supusesse (cf. Rocha, 2012, p. 21), mas em verdade o amplia.

A nova versão do primeiro parágrafo expressa, à absoluta diferença do texto de 1936, a proposta do livro como uma discussão das "possibilidades de se mudarem as raízes, as heranças culturais, a ordem vigente" (Cardoso, 1993, p. 30). Ou, em dizer de Gabriel Cohn que merece apenas um reparo, a proposta do livro passava a ser a "erradicação dos implantes malogrados" - melhor se diria dos transplantes exauridos - "e o preparo do solo para as novas personagens históricas" (Cohn, 2002, p. 11). Essas leituras condizem com a retificação dos objetivos da obra pelo autor: "Assim, antes de perguntar até que ponto poderá alcançar bom êxito a tentativa, caberia averiguar até onde temos podido representar aquelas formas de convívio, instituições e ideias de que somos herdeiros" ( $R B, 1956$, p. 15). O exame algo entusiasmado da formação de um tipo próprio de cultura cede espaço à pesquisa - circunspecta, e mesmo cética - da medida em que a tentativa de implante "poderá alcançar bom êxito". As formas de convívio, instituições e ideias herdadas não são mais motivo de orgulho, mas nem por isso o iberismo é suplantado pelo americanismo. A dificuldade da transição é palpável: "Se a forma de nossa cultura ainda permanece largamente ibérica e lusitana, deve atribuir-se tal fato sobretudo às insuficiências do 'americanismo', que se resume até agora, em grande parte, numa sorte de exacerbamento de manifestações estranhas" (idem). ${ }^{\text {? }}$

A conclusão dessa discussão serve também de justificativa para o encadeamento expositivo deste artigo. $\mathrm{O}$ sentido assumido pelo desterro ao longo da segunda e da terceira ediçôes é mais bem compreendido pela prévia identificação da direção das mudanças gerais do texto (até pela sutileza das alterações nos parágrafos iniciais da obra). A inversão do juízo positivo sobre a tradição ibérica e a reorientação da revolução em um rumo democrático alteram por inteiro a narrativa do livro. Esta se torna mais complexa com a passagem de uma proposta nítida de solução política para outra que, embora clara e articulada, envolve o que se viu ser uma irresolução. Da resignação com a cordialidade, a narrativa volta-se à tênue promessa de civilidade. Essa seria outra acepção do "sombreamento" já identificado nas mudanças feitas para a segunda edição (Waizbort,
2011). Diga-se de passagem que poucas avaliações do alcance das alterações poderiam ser menos exatas do que a que saudava o leitor no prefácio da terceira edição do livro, referindo-se a "algumas alteraçōes que não lhe afetam essencialmente o conteúdo”. A nova ordem enunciativa data de 1948, mas o autor ainda não se havia decidido, naquele momento, a projetá-la no incipit do texto. Quando o faz, em 1956, confirma, no tópico frasal, a dinâmica que agora perpassava toda a obra. Referido a ela, o desterro pode ser visto como a problemática condição existencial criada pela antítese entre cordialidade e civilização, que não se concluía, com a passagem do tempo, em nenhuma síntese. O desterro torna-se a forma visível, no texto, dessa aporia.

\section{Conclusão}

No prefácio de 1968 a Visão do Paraíso, Sergio Buarque informava que "uma das missōes do historiador [...] consiste em procurar afugentar do presente os demônios da história" (Holanda, 1996f, p. xvi). Era esse o propósito das versões pós-guerra de Raízes do Brasil, cujas referências a "um demônio pérfido e pretensioso" que inspirava os homens a se verem "diversos do que são" ( $R B, 1948$, p. 285) vinham desacompanhadas da narrativa favorável a uma retomada da tradição. Antes, o trato mefistotélico induzia os homens ao bovarismo e à negação das potencialidades da herança ibérica. Agora, era justamente a tentação do tradicionalismo o alvo de esconjuro.

Raizes do Brasil se transformara, com os sombreamentos, em uma "interpretação progressista do seu país" (Candido, 2004, p. 246). Os elementos que embasavam esta apreciação, de resto correta, não podiam ser encontrados na edição princeps da obra. Um benefício da abordagem diacrônica aqui proposta é, assim, poder situar com maior precisão as interpretações sobre o livro, evitando imprecisões que possam emergir em afirmaçōes sobre o autor ou dele próprio.

Veja-se apenas um par de exemplos. O primeiro é de 1986: "Há meio século, neste livro, Sergio deixou claro que só o próprio povo, tomando a iniciativa, poderia cuidar do seu destino. Isto faz dele um coerente radical democrático" (Candido, 2006b, p. 252). O segundo é de cinco anos antes: 
Mas acredito que ele [Raizes do Brasil] ainda tenha valor: o livro foi publicado em 1936, uma época muito dura para o Brasil, quase tão dura quanto a atual. E nele afirmo que uma revolução no Brasil não pode ser uma revolução de superfície: teria de ser uma revolução que levasse em conta todos os elementos mais aptos que estão por baixo. Essa é uma afirmação que já na época era difícil fazer (Holanda, 2004, p. 10).

Pelas razões que se alinham nessas passagens, esse "clássico de nascença" do pensamento social brasileiro somente parece haver reunido todos os atributos para fazer jus ao prestigioso status- notadamente no tocante à defesa da "emergência das camadas oprimidas da população" (Candido, 2006a, p. 247) - doze anos depois de sua publicação. A menos, naturalmente, que a razão para se considerar que o livro "já nasceu clássico" (Morse, 1990, p. 238) fosse o elogio da primeira edição ao iberismo como alternativa ao utilitarismo.

A ausência ou a presença do Ocidente no Brasil - e deste naquele - é uma das questôes mais desafiadoras e elusivas que se assinalam nesse quadro, no qual talvez se possa vislumbrar, por novo ângulo (cf. Mammì, 2005), uma paisagem de ruínas modernas. Por ora, não se faz mais que apontar esse campo de discussão aberto pelo movimento de Raízes do Brasil rumo à abordagem negativa da tradição, positiva da revolução e aporética do desterro. Conclua-se, apenas, que o resultado da descontinuidade entre algumas das perguntas decisivas e das respostas cruciais que o texto oferecia em 1936 e que passou a oferecer em 1948 e em 1956 foi uma mudança na narrativa do livro, que se afastou da resignação pragmática com a cordialidade e se aproximou ceticamente de uma promessa de civilidade. Desta fez-se, em considerável medida, o mérito e a resistência deste "clássico por amadurecimento".

\section{Notas}

1 A grafia de todas as passagens transcritas do livro foi atualizada. As citaçôes de Raizes do Brasil neste artigo, que indicarão apenas o ano da edição e a página, referem-se a Holanda (1936; 1948; 1956; 2006).

2 A expressão, bem como a proposta de estudo siste- mático dessa perspectiva, é de João Cezar de Castro Rocha (2004; 2005; 2012). Outros trabalhos nessa linha são os de Robert Wegner (2000; 2006), Leopoldo Waizbort (2011), Alfredo Cesar Melo (2011) e João Kennedy Eugênio (2011). Ao último o autor só teve acesso durante a revisão deste artigo, não havendo podido senão mencioná-lo de passagem aqui.

3 Adaptação livre da "sintaxe da frustração" que Paulo Arantes (2004) recupera de Anatol Rosenfeld. A ideia é próxima, também, daquela de "arqueologia da ausência", que Rocha define como uma "avaliação das produções culturais que se baseia na identificação da ausência deste ou daquele elemento, ao invés da análise dos fatores que efetivamente definem o produto cultural estudado" (Rocha, 2003, p. 22n).

4 Esse padrão internacional será associado, à frente, ao "europeísmo carregado" que Sergio Buarque situa no além-Pirineus. A ideia desse padrão relaciona-se ao que Paulo Esteves, em um diálogo com o pensamento de Martin Wight, denominou "doutrinas de legitimidade" do internacional moderno. "Doutrinas de legitimidade' podem ser vistas como o núcleo da sociedade internacional, na medida em que elas predizem a maneira segundo a qual uma comunidade política deve se estruturar para ser reconhecida como sua parte integrante. A política de poder é, enfim, não só o emprego da força, mas a imposição de uma doutrina de legitimidade de acordo com a qual os sujeitos da sociedade internacional precisam ser constituídos" (Esteves, 2010, p. 238). Sergio Buarque não aborda esse tema senão de passagem, mas com atilamento característico, ao referir-se às políticas interna e externa do Segundo Reinado: "Modelamos a norma de nossa conduta entre os povos pela que seguem ou parecem seguir os países mais cultos, e então nos envaidecemos da ótima companhia" ( $R B, 1936$, p. 144, grifos acrescentados). O trecho figuraria em todas as edições do livro.

5 A avaliação do sentido de outro conjunto de alterações ao capítulo seis na edição de 1948 , referente à discussão das teses de Max Weber em $A$ ética protestante e o espirito do capitalismo, pode ser encontrada em Wegner (2000, pp. 58-64).

6 Não se desconhece, porém, que mesmo a nostalgia poderia estar a serviço de propósitos de resto concretos em Casa-grande \& senzala, à medida que se aproximava do mítico (Lima, 2005, Prefácio). Ver, em todo caso, a exposição de Ricardo Benzaquen de Araújo (2000) sobre as afinidades entre Raízes do Brasil e Sobrados e mucambos.

7 Os versos originais são: "Wandering between two 
worlds, one dead/ The other powerless to be born" (Arnold, 1994, p. 71).

8 Outra estratégia de interpretação poderia privilegiar o jogo de referências de cunho geográfico que perpassa todo o primeiro parágrafo do capítulo inicial (ver, por exemplo, Sallum Jr., 2012, p. 44). Fala-se em "clima tropical e subtropical", "território", "ambiente", "paisagem". O desterro de que fala Sergio Buarque seria, assim, entre qualquer tipo de cultura europeia (ibérica ou não) e a circunstância geográfica do Novo Mundo, "ambiente muitas vezes desfavorável e hostil” ( $R B, 1936$, p. 3). Quiçá se pudesse ouvir, nessa descrição, um eco do juízo de Gilberto Freyre, três anos antes, sobre a geografia que aguardava o português na América: "Tudo era aqui desequilíbrio. Grandes excessos e grandes deficiências, as da nova terra" (Freyre, 2003, p. 77). Mas essa leitura carece, ao que tudo indica, de amparo no argumento de Raizes do Brasil, cujo segundo capítulo estende-se na demonstração da excelente adaptação do colonizador ao espaço americano: "Procurando recriar aqui o meio de sua origem, fizeram-no com uma destreza que ainda não encontrou segundo exemplo na história" $(R B, 1936$, p. 25).

9 É interessante notar que em 1941, a meio caminho entre a primeira e a segunda ediçōes do livro, e no contexto da "fase americana" do autor (Wegner, 2000, cap. 3), Sergio Buarque começasse a prospectar pontos de contato entre os dois campos: "apesar de tudo quanto nos distingue dos anglo-saxôes da América, ainda restam zonas de coincidência nascidas já nas primeiras épocas da colonização e que o tempo não apagou. Delas resultam fatores de solidariedade ou, pelo menos, terrenos de possível entendimento, que podem ser alargados" (Holanda, 2012, pp. 24-27). Era nítida a diferença para a posição de juventude, em 1920: "O utilitarismo yankee não se coaduna absolutamente com a índole do povo brasileiro, que não tem semelhança alguma com a do norte-americano da qual é o extremo oposto [...]. O nosso desideratum é o caminho que nos traçou a natureza, só ele nos fará prósperos e felizes, só ele nos dará um caráter nacional de que tanto carecemos. E o caminho que nos traçou a natureza é o que nos conduzirá a Ariel, sempre mais nobre e digno do que Caliban" (Holanda, 1996b, pp. 44-45).

\section{BIBLIOGRAFIA}

ADORNO, Theodor. (2008), Notas de literatura I, São Paulo, Duas Cidades/Editora 34.
ANDRADE, Oswald de. (2001), A utopia antropofágica, São Paulo, Globo.

ARANTES, Paulo Eduardo. (2004), Zero à esquer$d a$, São Paulo, Conrad. (2006), "Nação e reflexão", in B. Abdala Jr. e S. de A. Cara (orgs.), Moderno de nascença: figuraçôes críticas do Brasil, São Paulo, Boitempo.

ARAÚJO, Ricardo Benzaquen de. (2000), "Sobrados e mucambos e Raizes do Brasil", in M. C. T. de Miranda, Que somos nós?: 60 anos Sobrados e mucambos, Recife, Fundação Joaquim Nabuco/Editora Massangana; Núcleo de Estudos Freyrianos.

ARNOLD, Matthew. (1994), Dover beach and other poems, Nova York, Dover Publications.

AVELINO FILHO, George. (1987), "As raízes de Raizes do Brasil'. Novos Estudos, 18: 33-41. (1990), "Cordialidade e civilidade em Raizes do Brasil'. Revista Brasileira de Ciências Sociais, 5 (12): 5-15.

BOSI, Alfredo. (2003), "Homenagem a Sérgio Buarque de Holanda", in A. Bosi, Céu, inferno: ensaios de critica literária e ideológica, São Paulo, Duas Cidades/Editora 34.

CANDIDO, Antonio. (1998), "A visão política de Sérgio Buarque de Holanda", in A. Candido (org.), Sérgio Buarque de Holanda e o Brasil, São Paulo, Fundação Perseu Abramo. (2004), "Sergio em Berlim e depois", in A. Candido, Vários escritos, Rio de Janeiro/ São Paulo, Ouro sobre Azul/Duas Cidades. (2006A), "O significado de Raizes do Brasil", in S. B. de Holanda, Raizes do Brasil, R. B. de Araújo e L. M. Schwarcz (eds.), São Paulo, Companhia das Letras. (2006B), "Post-scriptum", in S. B. de Holanda, Raizes do Brasil, R. B. de Araújo e L. M. Schwarcz (eds.), São Paulo, Companhia das Letras.

CARDOSO, Fernando Henrique. (1993), "Livros que inventaram o Brasil'. Novos Estudos, 37: 21-35.

COETZEE, John Maxwell. (2002), "What is a classic? A lecture", in J. M. Coetzee, Stranger shores: essays 1986-1999, Londres, Vintage Books. 
COHN, Gabriel. (2002), "O pensador do desterro", Folha de S. Paulo, 23 de junho.

COUTO, Rui Ribeiro. (2006), "El hombre cordial, producto americano", in S. B. de Holanda, $R a$ izes do Brasil, R. B. de Araújo e L. M. Schwarcz (eds.), São Paulo, Companhia das Letras.

ESTEVES, Paulo. (2010), "Operaçōes de manutenção da paz sob o programa da paz democrática”, in M. Cepik (ed.), Segurança internacional, São Paulo, Hucitec.

EUGÊNIO, João Kennedy. (2011), Ritmo espontâneo: organicismo em Raízes do Brasil de Sérgio Buarque de Holanda, Teresina, EDUFPI.

FINAZZI-AGRÒ, Ettore. (2005), "A trama e o texto: história com figuras", in S. J. Pesavento (org.), Um historiador nas fronteiras: o Brasil de Sérgio Buarque de Holanda, Belo Horizonte, Editora UFMG.

FREYRE, Gilberto. (1936), "Prefácio", in S. B. de Holanda, Raizes do Brasil, Rio de Janeiro, José Olympio.

(2003), Casa-grande \& senzala: formação da família brasileira sobre o regime da economia patriarcal, São Paulo, Global.

HOLANDA, Sergio Buarque de. (1936), Raizes do Brasil, Rio de Janeiro, José Olympio.

(1948), Raizes do Brasil. 2 ed., revista e ampliada. Rio de Janeiro/São Paulo, José Olympio.

. (1956), Raizes do Brasil. 3 ed., revista e ampliada. Rio de Janeiro, José Olympio.

(1988), "O Estado totalitário", in F. de A. Barbosa (org.), Raizes de Sergio Buarque de Holanda, Rio de Janeiro, Rocco.

(1996a), "A cidade verde", in S. B. de Holanda, $O$ espirito e a letra: estudos de critica literária, A. A. Prado (org.), São Paulo, Companhia das Letras, vol. 1.

(1996b), "Ariel", in S. B. de Holanda, O espirito e a letra: estudos de critica literária, A. A. Prado (org.), São Paulo, Companhia das Letras, vol. 1.

(1996c), "Erudição e imaginação", in

S. B. de Holanda, O espírito e a letra: estudos de crítica literária, A. A. Prado (org.), São Paulo, Companhia das Letras, vol. 2. . (1996d), "Fluxo e refluxo III", in S.
B. de Holanda, $O$ espirito e a letra: estudos de crítica literária, A. A. Prado (org.), São Paulo, Companhia das Letras, vol. 2.

(1996e), "Notas sobre o romance", in

S. B. de Holanda, O espirito e a letra: estudos de crítica literária, A. A. Prado (org.), São Paulo, Companhia das Letras, vol. 1.

(1996f), Visão do paraíso: os motivos

edênicos no descobrimento e colonização do Brasil, São Paulo, Brasiliense.

. (2004), "Corpo e alma do Brasil: entrevista de Sérgio Buarque de Holanda”. Novos Estudos, 69: 3-14.

- (2006), Raizes do Brasil, R. B. de Araújo e L. M. Schwarcz (eds.), São Paulo, Companhia das Letras.

(2011a), "Corpo e alma do Brasil: ensaio de psicologia social”, in S. B. de Holanda, Escritos coligidos: livro I, 1920-1949, M. Costa (org.), São Paulo, Editora da Unesp/Fundação Perseu Abramo, vol. 1.

. (2011b), "O homem-máquina", in S. B. de Holanda, Escritos coligidos: livro I, 19201949, M. Costa (org.), São Paulo, Editora da Unesp/Fundação Perseu Abramo, vol. 1.

. (2012), "Consideraçôes sobre o americanismo", in S. B. de Holanda, Cobra de vidro, São Paulo, Perspectiva.

LEITE, Dante Moreira. (1976), O caráter nacional brasileiro: história de uma ideologia, São Paulo, Pioneira.

LIMA, Luiz Costa. (2005), O romance em Cornélio Penna, Belo Horizonte, Editora UFMG.

MACHADO, Brasil Pinheiro. (2008), "Raizes do Brasil: uma releitura”, in P. M. Monteiro e J. K. Eugênio, Sérgio Buarque de Holanda: perspectivas, Campinas/Rio de Janeiro, Editora da Unicamp/EdUERJ.

MAMMÌ, Lorenzo. (2005), "Encalhes e desmanches: ruínas do modernismo na arte contemporânea brasileira", in s./a., VI Simposio internacional diálogos ibero-americanos: reenfocando visiones, problemas y posibilidades en el arte contemporáneo, Valência, Ed. Ivan Valencia/Instituto de Arte Moderna/Fundación Astroc.

MELO, Alfredo Cesar. (2011), "Lusitanian roots and Iberian heritage in Raizes do Brasil'. Por- 
tuguese Studies, 27 (1): 78-94.

MONTEIRO, Pedro Meira. (1999a), A queda do aventureiro: aventura, cordialidade $e$ os novos tempos em Raízes do Brasil, Campinas, Editora da Unicamp.

. (1999b), "Sergio Buarque de Holanda e as palavras: uma polêmica". Lua Nova, 48: 145-159.

. (2008), "Uma tragédia familiar", in P. M. Monteiro \& J. K. Eugênio, Sérgio Buarque de Holanda: perspectivas, Campinas/Rio de Janeiro, Editora da Unicamp/EdUERJ. . (2010), "As Raizes do Brasil em O espelho de Próspero", in B. H. Domingues e P. L. Blasenheim (orgs.), O código Morse: ensaios sobre Richard Morse, Belo Horizonte, Editora UFMG. . (2012a), "Coisas sutis, ergo profundas': o diálogo entre Mario de Andrade e Sérgio Buarque de Holanda", in M. de Andrade e S. B. de Holanda, Correspondência, P. M. Monteiro (orgs.), São Paulo, Companhia das Letras/ Instituto de Estudos Brasileiros (USP)/Edusp. (2012b), Foreword: why read Roots of Brazil today?, in S. B. de Holanda, Roots of Brazil, Notre Dame, Ind., University of Notre Dame Press.

MORSE, Richard McGee. (1990), "A formação do latino-americanista", in R. M. Morse, A volta de McLuhanaima: cinco estudos solenes e uma brincadeira séria, São Paulo, Companhia das Letras.

NIETZSCHE, Friedrich. (2011), El anticristo: maldición del cristianismo, Madri, Mestas Ediciones.

PIVA, Luiz Guilherme. (2000), Ladrilhadores e semeadores: a modernização brasileira no pensamento politico de Oliveira Viana, Sérgio Buarque de Holanda, Azevedo Amaral e Nestor Duarte (1920-1940), São Paulo, Editora 34.

RICARDO, Cassiano. (1959), O homem cordial e outros pequenos estudos brasileiros, Rio de Janeiro, Instituto Nacional do Livro.

ROCHA, João Cezar de Castro. (2003), “'Nenhum Brasil existe': poesia como história cultural", in J. C. de C. Rocha, Nenhum Brasil existe: pequena enciclopédia, Rio de Janeiro, EdUERJ/ Topbooks/UniverCidade Editora.
(2004), O exilio do homem cordial: ensaios e revisóes, Rio de Janeiro, Museu da República.

(2005), "O nada que é tudo. Ou: a cordialidade nossa de cada dia”, in J. C. de C. Rocha, Cordialidade à brasileira mito ou realidade?, Rio de Janeiro, Museu da República. . (2012), "Sergio Buarque de Holanda e Gilberto Freyre: raízes de uma rivalidade literária". Dicta\&contradicta, 9: 10-28.

ROUANET, Sergio Paulo. (2006), "Desterrados na própria terra”, O Estado de S. Paulo, 22 de outubro.

SALLUM JR., Brasilio. (2012), “As raízes do Brasil e a democracia". Sinais sociais, 7(19): 40-59.

SANTIAGO, Silviano. (2006), As raízes e o labirinto da América Latina, Rio de Janeiro, Rocco.

SMITH, Herbert Huntington. (1879), Brazil: the Amazons and the coast, Nova York, Charles Scribner's Sons.

(1922), Do Rio de Janeiro a Cuiabá, Caieiras/São Paulo/Rio de Janeiro, Companhia Melhoramentos de São Paulo.

VARGAS, Everton Vieira. (2007), O legado do discurso: brasilidade e hispanidade no pensamento social brasileiro e latino-americano, Brasília, Fundação Alexandre de Gusmão.

VECCHI, Roberto. (2005), "Atlas intersticial do tempo do fim: 'Nossa revolução"”, in S. J. Pesavento (org.), Um historiador nas fronteiras: 0 Brasil de Sergio Buarque de Holanda, Belo Horizonte, Editora UFMG.

WAIZBORT, Leopoldo. (2011), "O mal-entendido da democracia: Sergio Buarque de Hollanda, Raízes do Brasil, 1936". Revista Brasileira de Ciências Sociais, 26 (76): 39-62.

WEGNER, Robert. (2000), A conquista do Oeste: a fronteira na obra de Sergio Buarque de Holanda, Belo Horizonte, Editora UFMG.

(2006), "Um ensaio entre o passado e o futuro", in S. B. de Holanda, Raizes do Brasil, R. B. de Araújo e L. M. Schwarcz (eds.), São Paulo, Companhia das Letras.

(2009), "Caminhos de Sérgio Buarque de Holanda", in A. Botelho e L. M. Schwarcz (orgs.), Um enigma chamado Brasil, São Paulo, Companhia das Letras. 


\section{UM CLÁSSICO POR AMADURECIMENTO: RAÍZES DO BRASIL}

\section{Luiz Feldman}

Palavras-chave: Sergio Buarque de Holanda; Raizes do Brasil; Cordialidade; Civilidade; Democracia.

Este artigo analisa as transformações do texto original de Raizes do Brasil, publicado em 1936, na segunda e terceira edições, respectivamente de 1948 e 1956. As alteraçōes realizadas por Sergio Buarque de Holanda foram de três ordens: inversão da avaliação positiva do legado ibérico na formação brasileira; substituição da solução política personalista para os desafios da nascente ordem urbana por uma solução democrática; e a revisão do diagnóstico sobre a transposição bem-sucedida do que denomina "cultura europeia" para o Brasil. Com isso, a narrativa do livro afastou-se de uma pragmática resignação com a cordialidade e aproximou-se ceticamente a uma promessa de civilidade. Conclui-se que, a julgar pelo critério da defesa da democracia, Raízes do Brasil só pode ser dito um clássico após esse movimento.

\section{A CLASSIC BY MATURATION: ROOTS OF BRAZIL}

\section{Luiz Feldman}

Keywords: Sergio Buarque de Holanda; Raizes do Brasil [Roots of Brazil]; Cordiality; Civility; Democracy.

This article analyses how the original text of Raizes do Brasil, published in 1936, was modified in the second and third editions, dated 1948 and 1956, respectively. The changes made by Sergio Buarque de Holanda fall into three broad categories: an inversion of the positive view of the Iberian legacy's role in Brazilian development; the replacement of personalism by democracy as a political solution to the challenges posed by the emerging urban order; and the reformulation of the diagnosis on the well succeeded transposition of what he call the "European culture" to Brazil. Thus, the book's narrative was drawn away from a pragmatic resignation to cordiality and came, albeit skeptically, closer to a promise of civility. The article concludes that, considered by the criterion of the defense of democracy, Raizes do Brasil can only be said to be a classic after such movement.

\section{UN CLASSIQUE PAR MATURATION: RACINES DU BRÉSIL}

\section{Luiz Feldman}

Mots-clés: Sergio Buarque de Holanda; Raizes do Brasil; Cordialité; Civilité; Démocratie.

Cet article analyse les transformations du texte original de Raízes do Brasil (Racines du Brésil), publié en 1936, dans ses seconde et troisième éditions publiées, respectivement, en 1948 et en 1956. Les modifications entreprises par Sergio Buarque de Holanda ont été de trois ordres: inversion de l'évaluation positive de l'héritage ibérique dans la formation brésilienne; substitution de la solution politique personnaliste pour les défis de l'ordre urbain naissant par une solution démocratique ; et révision du diagnostic sur la transposition bien succédée de ce que l'auteur appelle " culture européenne " pour le Brésil. Avec ces changements, la narration du livre s'est éloignée d'une résignation pragmatique avec la cordialité et s'est approchée sceptiquement d'une promesse de civilité. Nous concluons, à en juger par le critère de défense de la démocratie, que Raizes do Brasil ne peut être considéré un classique qu'après ce mouvement. 